\title{
Virtuaalinen ryhmämentorointi ammattikorkeakouluopettajan kehittymisen tukena
}

IRJA LEPPISAARI, SEIJA MAHLAMÄKI-KULTANEN \& LEENA VAINIO

\begin{abstract}
Millainen oppimistila muodostuu virtuaalisessa ryhmämentoroinnissa? Virtuaaliammattikorkeakoulun verkkopedagogisessa projektissa kokeneemmat asiantuntijat tukivat virtuaalisella ryhmämentoroinnilla opettajaryhmiä verkkoaineistojen arvioinnissa ja vertaisoppimisessa. Projektiin liittyvässä tutkimuksessa selvitettiin, miten virtuaalinen ryhmämentorointi tuki opettajien osaamisen kehittymistä ja mitä opettajat kokiva oppivansa. Tulokset olivat rohkaisevia. "Opin toimimaan luontevasti v erkon välityksellä, uutuudenviehätys vaihtui normaalitoiminnaksi", kuului yhden osallistujan palaute... ja siihen yhtyivät useimmat.
\end{abstract}

M uuttuva työelämä ja uudet vaativat työtehtävät edellyttävät opettajalta oman osaamisen jatkuvaa arviointia ja kehittämistä. Substanssiosaamisen lisäksi oman osaamisen kehittäminen metataitona, esimerkiksi kyky reflektiivisyyteen ja kriittiseen tiedon arviointiin, uusien oppimisympäristöjen edellyttämät kommunikaatio- ja yhteistyötaidot sekä kyky jatkuvaan uuden oppimiseen ja luomiseen ovat välttämättömiä (Collin 2007).

Opettajien verkkopedagogisen osaamisen kehittämisohjelmia koskevista tutkimuksista tehty laaja meta-analyysi nosti esille kriittisiä suunnittelunäkökulmia, kuten kehittämisohjelman tyypin, sisällön, keston ja teknisen tuen (Lawless \& Pellegrino 2007, 604). Miten perinteisten ja kertaluontoisten osaamisen kehittämiskeinojen tilalle voidaan luoda joustavampia malleja? Esimerkiksi virtuaaliset mallit vastaavat perinteistä täydennyskoulutusta paremmin muuttuviin yksilöllisiin osaamistarpeisiin, mutta edellyttävät ajattelun muutosta, uutta asiantuntijanäkemystä ja kollegiaalista osaamisen jakamista. (Lock 2006, 664-665.) Työhön kytkeytyvän osaamisen kehittäminen on perusteltavissa sekä teoreettisesti että käytännön järjestelyjen kannalta (ks. esim. Hytönen 2007; Lock 2006, 666).
Virtuaalinen mentorointi ei ole vielä kovin yleistä, mutta tutkimukset osoittavat sitä kokeilleiden opettajien olleen tyytyväisiä, muuttaneen asenteitaan ja opetuskäytänteitään. Toimintatavan uutuudesta ja erityisluonteesta johtuen valtaosa tehdystä tutkimuksesta on tapaustutkimuksia, joissa jossain erityisessä toimintaympäristössä yhdessä vapaaehtoisen (asiantuntija)ryhmän kanssa kehitetään ja tutkitaan virtuaalista mentorointia. (Gentry, Denton \& Kurz 2008.) On haasteellista laatia selkeää vaikuttavuustutkimusta tai koeasetelmaa, jossa vertaillaan opettajan osaamisen kehittymisen muotoja, koska opettajan työ ja oppiminen asiantuntijayhteisössä kietoutuvat toisiinsa aiemmasta perustavasti poikkeavalla tavalla. (Lock 2006, 666). Ekspansiivinen, horisontaalinen oppiminen kollegaverkostoissa (vrt. Tuomi-Gröhn, Engeström \& Young 2003) tuottaa ammattikorkeakouluopettajan työn edellyttämää kollektiivista asiantuntijuutta.

Tässä artikkelissa raportoidaan Suomen Virtuaaliammattikorkeakoulussa tehdyn toimintatutkimuksen tuloksia virtuaalisesta ryhmämentoroinnista, jonka avulla haluttiin tukea opettajia laadun kehittämishankkeessa heidän arvioidessaan verkko-opintojaksoja ja samalla kehittää heidän osaa- 
mistaan esimerkiksi reflektiossa ja verkkopedagogiikassa. Luotettavuuden ja toimintamallin siirrettävyyden arvioimiseksi kontekstin kuvaus tehdään yksityiskohtaisesti (ks. Lawless \& Pellegrino 2007, 601-602).

\section{Teoreettinen viitekehys}

\section{Jaettu asiantuntijuus yhteisöllisessä oppi- mistilassa}

Asiantuntijuuden kehityspolulla eri vaiheissa olevien kesken voidaan ratkaista ongelmia, kehittää toinen toistensa ajattelua ja yhteistä kohdetta ja tuottaa kollektiivista, jaettua asiantuntijuutta (vrt. Hakkarainen, Palonen, Paavola \& Lehtinen 2004). Työstä eli tässä kuvatussa tutkimuksessa verkkoopintojaksojen laadun kehittämisprojektista voi muodostua oppimistila (learning space), jos projektin osallistujat vaihtavat ajatuksiaan, tietojaan, kokemuksiaan ja tunteitaan reflektiivisellä ja autenttisella tavalla (ks. Docherty, Boud \& Cressey 2006; Boud 2006).

\section{Ryhmä- ja vertaismentorointi virtuaalisen oppimisyhteisön tukena}

Mentorointi on reaaliaikainen asiantuntijuuden jakamisen ja kehittämisen menetelmä. Mentorointi edistää hiljaisen, kokemusperäisen tiedon ja osaamisen julkituomista. (Hezlett \& Gibson 2005.) Perinteisesti mentorointi toteutuu kahden vertaisen kesken henkilökohtaisesti tavaten (Gentry ym. 2008, 340). Ryhmämentoroinnissa ryhmän jäsenillä on yhteinen syy olla vuorovaikutuksessa mentorinsa kanssa samanaikaisesti (vrt. Leskelä 2007, 166-167). Ryhmällä voi olla yksi tai useampi mentori (Welsh 2004).

Mentorointisuhteita voidaan muodostaa vertaisten kesken omassa organisaatiossa tai yli organisaatiorajojen rakentuvissa kollegiaalisissa kolleegaverkostoissa. Niihin voivat osallistua myös muita kokeneemmat asiantuntijamentorit. (Klasen \& Clutterbuck 2004; Le Cornu 2005.) Oppimisyhteisössä on aina tavoitteena tasaveroisuus ja uusien yhteyksien luominen (Le Cornu 2005). Jopa kokonaiset tiimit tai organisaatiot voivat mentoroida toisiaan (inter-team mentoring) (Klasen \& Clutterbuck 2004).

Oppimisyhteisön jäsenet osallistuvat omaan oppimisprosessinsa lisäksi vertaisoppijoina toistensa oppimisprosesseihin ammatilliseen dialogin ja kollegiaaliseen tiedonrakentamisen avulla. Vertaismentorointia voidaan vahvistaa ryhmämentoroinnissa siten, että ryhmän vetäjä toimii sekä kokeneempana asiantuntijamentorina että aktivoi vertaismentorointia. Vertaiset jakavat mentoroidessaan keskenään ongelmia, ratkaisustrategioita, ammatillista tietoa, kiinnostusta, emotionaalista tukea, palautetta ja oppivat toisiltaan (Klasen \& Clutterbuck 2004; Welsh 2004). Vertaisoppiminen on perinteiseen mentorointiin osallistumista dynaamisempi ja tasavertaisempi vuorovaikutus-, tiedontuottamis- ja oppimisprosessi (Colky \& Young 2006, 441; Le Cornu 2005). Vertaismentorointi voi edistää oppimista ja synergiaa, ideoiden ja kokemusten keskinäistä jakoa sekä tiimityötaitoja (McDougall \& Beattie 1997).

Teknologiset välineet voivat helpottaa monenvälisten mentorointiyhteisöjen toimintaa. Virtuaalinen ryhmämentorointi määritellään oppimistilaksi ja oppimisyhteisölliseksi prosessiksi, jonka avulla vertaiset keskenään tai asiantuntijamentorin tukemana tuottavat uutta tietoa, taitoa, tulkintoja ja merkityksiä (Le Cornu 2005). Virtuaalinen oppimisyhteisö voi koostua esimerkiksi teemoittain muodostuneista väljärajaisista yhteisöistä. Ryhmän virtuaalitapaamiset ovat reaaliai-

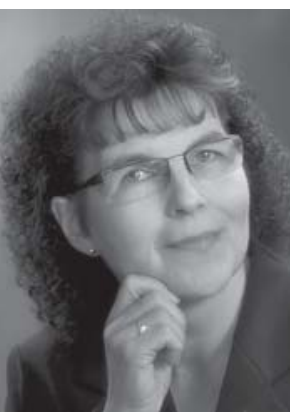

Irja Leppisaari

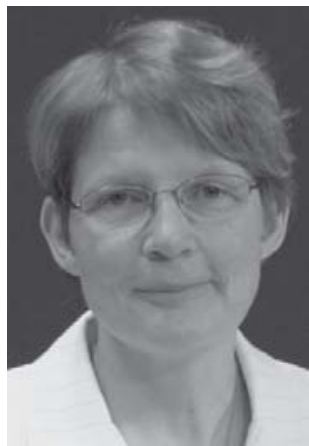

Seija MahlamäkiKukltanen

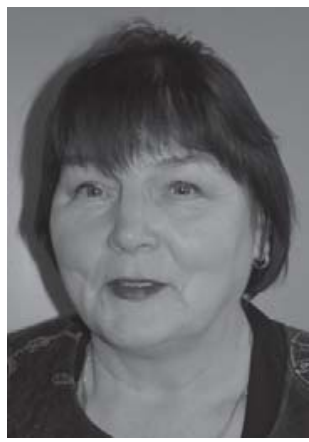

Leena Vainio kaisia (virtuaalipalaveri, videoneuvottelu), eriaikaisia (oppimisalusta, esim. Moodle, WebCT) tai viestintämuotoja yhdistellään.

\section{Virtuaaliammattikorkeakoulun kehittä- misprojekti tutkimuksen kohteena}

Suomen Virtuaaliammattikorkeakoulu on ammattikorkeakoulujen muodostama yhteistyö- ja asiantuntijaverkosto, jolla on yhteinen virtuaaliopetuksen ja verkkopedagogiikan kehittämisen kohde ja 
visio (vrt. Hakkarainen \& Paavola 2007, 243). Keskeisiä toimintatapoja ovat jaettujen käytäntöjen neuvottelu verkostossa ja kokemusten työstäminen uusiksi käytänteiksi Virtuaaliammattikorkeakoulun eri hankkeissa.

Vuonna 2007 Virtuaaliammattikorkeakoulussa toteutettiin ESR-osarahoitteinen kymmenen kuukauden mittainen kehittämisprojekti, jossa virtuaalisella ryhmämentoroinnilla tuettiin seuraavia projektin kolmea päätavoitetta:

1. ammattikorkeakouluopettajien muodostamissa tuotantorenkaissa vuosina 2003-2006 tuotetun, vapaasti kaikkien ammattikorkeakoulujen hyödynnettävissä olevan DIGMA-metatietovarannon (www.amk.fi) verkkoaineiston laadunvarmistus

2. aineistojen tunnettuuden ja aktiivisen käytön edistäminen

3. uudenlaisen verkkopedagogisen osaamisen kehittämisen toimintamallin rakentaminen.

Projektin yhteinen työn ja kehittämisen kohde oli verkkoaineistojen pedagoginen laadunarviointi. Jaettuja kohteita voivat olla Hakkaraisen ja Paavolan (2006, 241) mukaan välineet, menetelmät, käsitteet ja teoriat. Tässä projektissa jaettuina kohteina olivat sekä projektissa arvioitavat aineistot, pedagogisessa laadun arvioinnissa tarvittava tietämys, laadun arvioinnin kriteerit ja työkalut sekä verkko-opintojaksojen laadunarviointiprosessi. Projektin toinen ja kolmas tavoite kytkeytyivät laadunarviointiin.

Projekti tarjosi aineistoja arvioiville opettajille mahdollisuuden kehittää osaamistaan monin eri tavoittein: virtuaaliopetus, virtuaalitiimityöskentely, vertaisarviointi, pedagoginen laatutyö, modernit mentoroinnin muodot, verkosto-osaaminen ja digitaalisten työkalujen käyttö. Tässä oli virtuaalisen ryhmämentoroinnin toimintamallin keskeinen haaste ja samalla mahdollisuus. Projektiin osallistui 31 opettajaa kahdestatoista ammattikorkeakoulusta. Opettajista muodostettiin kuusi pääasiassa koulutusalakohtaista arviointiryhmää. Niiden mentoreiksi kutsuttiin kuusi verkkopedagogiikan asiantuntijaa. Projektin koordinaattoreina toimivat artikkelin kirjoittajista Leppisaari ja Vainio.

Mentorointiprojektista haluttiin muodostaa eri keinoin virtuaalinen oppimisyhteisö (ks. Lewis \& Allan 2005). Projektin tavoitteet olivat ammattikorkeakouluverkoston virtuaaliopetuksen kehittämisja arviointitarpeiden mukaisia. Toiminta oli johdet- tua (projektin koordinaattorit, mentorit ryhmissä), jäsenet tulivat eri organisaatioista ja tietojen ja taitojen siirtymistä oppimisyhteisön ja opettajan työpaikan välillä tuettiin ohjauksen ja seminaarien avulla. Tunnusomaista toiminnan johtamisessa oli myös ongelmaratkaisun kollaboratiivinen lähestymistapa sekä yhteisöllinen ja rajoja ylittävä työskentely. (vrt. Lewis \& Allan 2005.) Keskeisin osaamisen kehittämisen keino oli virtuaalinen ryhmämentorointi, joka määriteltiin ja toteutettiin asiantuntijuuden kehittämisen ja jakamisen prosessina virtuaalisessa ympäristössä, vertaisten keskinäisessä ja asiantuntijamentoreiden tukemassa vuorovaikutuksessa (vrt. Leppisaari, Vainio, Kleimola, Hartnell-Young \& Makino 2006). Mentoreiden tehtävänä oli tukea arviointiryhmän kollektiivista reflektiota sekä jäsenten yksilöllistä reflektiota. Reflektiota ja oppimista mahdollistivat myös arviointiryhmien keskustelujen tallentuminen verkkoympäristöön.

Projekti toteutettiin virtuaalisissa työympäristöissä käyttämällä synkronisia ja asynkronisia kommunikaatiomahdollisuuksia. Ryhmien tapaamiset ja koulutukset järjestettiin viestintäjärjestelmä Acrobat Connect Pro:n (jatkossa Connect Pro) kautta ja tapaamisten välillä työskenneltiin Moodle-oppimisalustalla (jatkossa Moodle) ja sähköpostiyhteyksin. Connect Pro:ssa osallistujat voivat nähdä ja kuulla toisensa kameroiden ja mikrofonin kautta. Ohjelmiston kautta voidaan myös jakaa sama esitys kaikille ja tuottaa yhteistä dokumenttia. Istunnot, ryhmien arviointiprosessit ja yhteisesti tuotettu materiaali tallennettiin kaikkien nähtäviksi.

Projekti aloitettiin järjestämällä mentoreille kahden tunnin pituinen orientaatiokoulutus. Sen jälkeen toteutettiin mentoreiden ja aineistojen arviointiryhmien kesken yhteinen kolmen tunnin mittainen verkkoseminaari. Seminaarissa käytiin läpi kehittämisprojektin tavoitteet, työskentelymenetelmät ja käytettävät laadunarviointikriteerit. Koulutusten lisäksi tarjolla oli teknistä keskitettyä tukea digitaalisten työkalujen ja verkkoympäristön käyttöön.

Projektin vetäjät ohjasivat ja konsultoivat mentoreita virtuaalisissa mentoripalavereissa kerran kuukaudessa. Arvioijaryhmät kokoontuivat mentorinsa kanssa 4-5 kertaa projektin aikana ja lisäksi keskusteluja jatkettiin Moodle-oppimisalustalla. Tutkijoiden projektin alussa ja lopussa tekemien tutkimuskyselyjen funktio oli tukea reflektiota ja oppimista. Virtuaalisesti toteutetussa projektin 


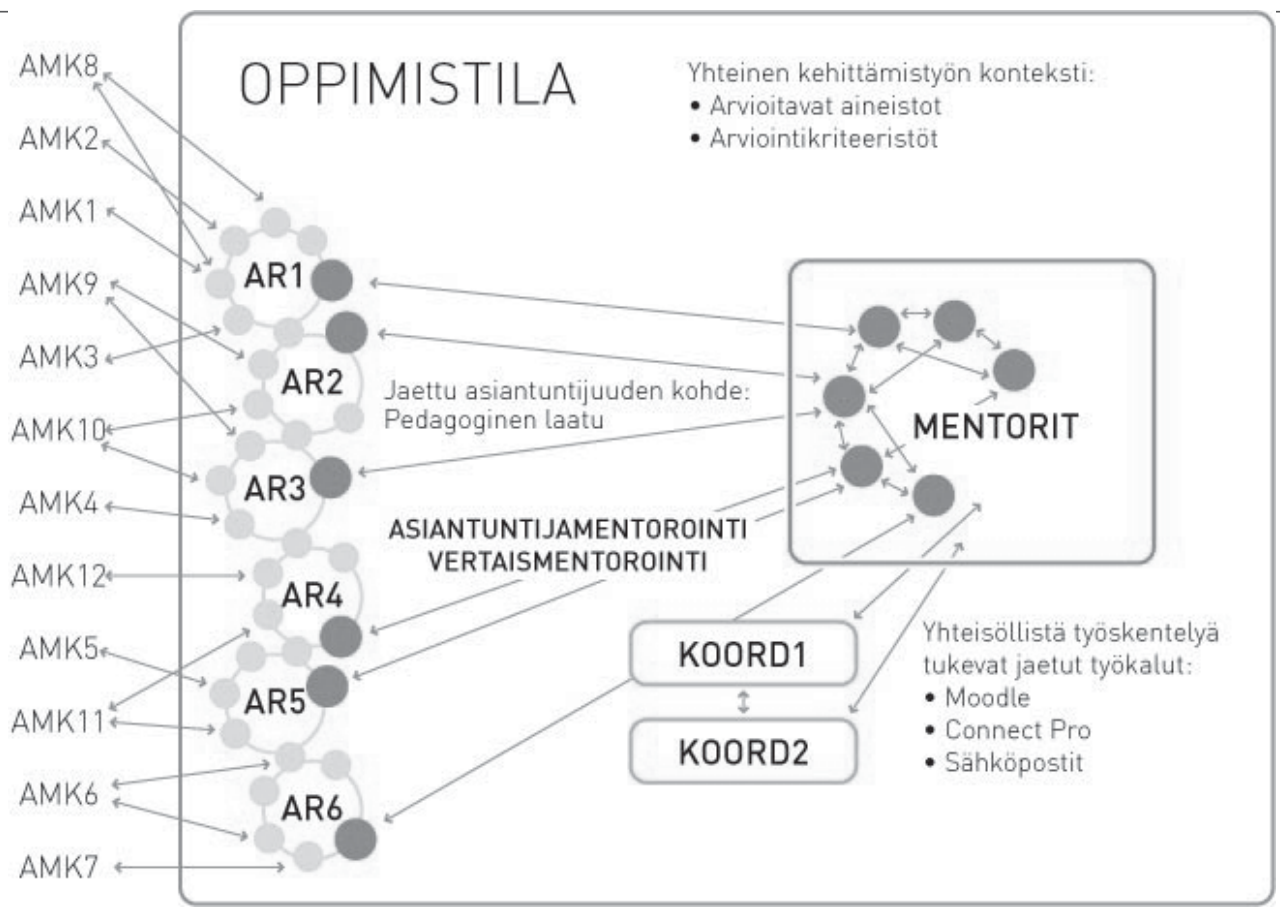

Kuvio 1. Kehittämisprojektin toteutus: Asiantuntijamentorointi ja vertaismentorointi oppimistilan luojina opettajien hajautetussa virtuaalisessa oppimisyhteisössä.

päätösseminaarissa kuvattiin ja arvioitiin ryhmien toimintaa ja projektin toteutusta.

Kehittämisprojektin toteutus on esitetty tiiviisti kuviossa 1, jossa kuvataan miten monenvälisiä suhteita ja virtuaalisen oppimisyhteisön ja -tilan rakentumista tuettiin ryhmämentoroinnin avulla. Kuviossa on kuvattu projektin kuusi erillistä arviointiryhmää (kussakin 4-6 opettajaa eri koulutusaloilta, 12 eri ammattikorkeakoulusta). Projektin toimintamallissa arviointiryhmillä (AR) oli omat arvioitavat aineistot ja sovelletut tavoitteet ja toimintatavat, mutta arvioinnissa tarvittava osaaminen oli samansisältöistä ja työskentely tapahtui yhteisellä verkkoalustalla ja yhteisissä seminaareissa. Oppimistilan ja -yhteisön oli tarkoitus laajentua koko projektin käsittäväksi ja jopa kasvattaa yhteyksiä ekspansiivisesti opettajien omiin työyhteisöihin.

\section{Tutkimuksen toteuttaminen}

Kehittämisprojektiin liittyvän tutkimuksen keskeiset käsitteet olivat oppimistila ja virtuaalinen ryhmämuotoinen asiantuntija- ja vertaismentorointi. Tarkentavat tutkimuskysymykset olivat:

. Miten opettajat määrittelivät oppimistilansa verkkomentoroinnin avulla tuetussa kehittämisprojektissa?

Mitä opettajat kokivat oppivansa?
Miten virtuaalinen ryhmämentorointi toimintatapana tuki opettajien osaamisen kehittymistä?

\section{Tutkimusaineistot}

Aineisto on trianguloitu ja se koostuu autenttisista virtuaalisen työskentelyn dokumentoituneista jäljistä, osallistujille kohdennetuista kyselyistä sekä projektin vetäjien pitämistä muistioista tapahtuneesta. Päätutkimusaineiston muodostavat maaliskuussa 2007 toteutetut alkukyselyt mentoreille ( $n=6)$ ja opettajille $(n=26)$ sekä lokakuussa 2007 tehdyn loppukyselyn aineistot. Loppukyselyyn vastasi 24 opettajaa ja neljä mentoria. Yhteensä kyselyaineisto koostuu siis 26/31 projektin opettajan sekä kaikkien kuuden mentorin vastauksista. Opettajien vastausprosentti oli 77,4 prosenttia. Kyselyt, jotka koostuivat pääosin avoimista kysymyksistä, toteutettiin Webropol-ohjelmalla Internetissä anonyyymisti. Alkukyselyn keskeiset teemat olivat verkko-opetus- ja virtuaalityöskentely- ja mentorointikokemusten kartoitus sekä omat oppimistavoitteet ja odotukset projektille, yhteensä yhdeksän kysymystä. Loppukysely sisälsi 1) oppimistilaan ja projektissa opittuun, 2) mentorointiin, 3) pedagogiseen laadunarviointiin sekä 4) projektin työtapaan ja työvälineisiin liittyviä kysymyksiä. Yhteensä loppukyselyssä oli 28 kysymystä. Täydentävää tutkimusaineistoa ovat projektin 
alku- ja päätösseminaarien litteroidut nauhoitteet $(\mathrm{n}=2)$, arviointiryhmien virtuaalipalavereiden litteroidut nauhoitteet $(n=10)$ sekä muistiot $(n=11)$ ja Moodle-oppimisalustaan tallentuneet jäljet koko projektin ajalta.

\section{Tutkimusmenetelmät}

Hankkeen toteuttamisessa sovellettiin toimintatutkimuksellista, lähinnä koulutuksellisin tavoittein painottunutta lähestymistapaa (ks. Suojanen 1992) ja pyrittiin tuottamaan relevanttia teoriaa käytännön toimijoiden käyttöön. Projektin vetäjien, tutkijoiden ja käytännön toimijoiden yhteistyö oli merkittävä tutkimusprosessin kulussa ja sisällöissä (vrt. Reeves, Herrington \& Oliver 2004). Tutkimusta tuki myös ulkopuolisen asiantuntijan kehittämiskonsultaatio mentoripalavereissa.

Pääosin laadullisia tutkimusaineistoja on analysoitu sisällönanalyyttisesti hyödyntäen Atlas.ti -ohjelmaa. Projektin vetäjät osallistuivat aktiivisina toimijoina tutkimusprosessiin ja aineiston analyysi tuki itsearviointia ja reflektion kautta oppimista. Mahlamäki-Kultanen varmisti hankkeen ulkopuolisena aineistojen analyysiä ja luotettavuutta ja osallistui kirjoittamiseen. Virtuaalista mentorointia koskevien aiempien tutkimusten tavallinen puute on ollut aineistojen analyysin jättäminen tarkistamatta, ulkoisen arvioinnin puute ja nojautuminen vain kokeiluihin osallistuneiden vapaaehtoisten itse raportoimiin tuloksiin. (ks. Gentry ym. 2008, 365.)

Toimintatutkimus eteni syklisesti sisältäen suunnittelun, toiminnan, havainnoinnin ja reflektion elementit, jotka ovat samalla olennainen osa osaamisen kehittämisen mallia. Osallistavan ja voimaannuttavan toimintatutkimuksen mukaisesti hankkeeseen osallistuneet opettajat voivat samalla kehittää omaa ammatillista ja verkkopedagogista osaamistaan sekä uusien toimintatapojen ja työkalujen käyttöä (ks. Cohen, Manion \& Morrison 2005; McNiff, Lomax \& Whitehead 2005.)

\section{TULOKSET -}

\section{Osaamisen kehittyminen virtuaalisessa oppimisyhteisössä}

\section{Oppimistilan määrittely}

Seuraavaksi tarkastellaan kuvion 1. pohjalta, miten opettajat määrittelivät oppimistilansa tarjolla olevista elementeistä ja mitkä olivat oppimistilan määrittelyssä ilmenneet jännitteet ja piirteet.

Vaikka Dochertyn ja kumppaneiden (2006) määrittely oppimistilasta korostaa yhteisöllisen oppimisen merkitystä ja projektin tavoitteena oli kollaboratiivinen vuorovaikutus, tutkimuksessa oppimistilan määrittelyn keskeinen jännite vallitsi $y h$ teisöllisyyden ja yksilöllisyyden välillä. Osallistujien toimintatavat vaihtelivat ryhmittäin yksilöpainotteisista yhteisöllisiin. Useissa ryhmissä projektin aineistojen arvioinnit tehtiin pääsääntöisesti työparin kanssa ja vain kolme kuudesta ryhmästä toimi melko yhteisöllisesti. Parviainen $(2006,165)$ huomauttaakin, että tiedon rakentaminen yhdessä saatetaan kokea vaativampana ponnistuksena kuin toimiminen yksin. Vaikka asiantuntijuus määritellään tänä päivänä nimenomaan yhteisöllisenä ominaisuutena, todellisuus näyttää olevan helposti toisenlainen. Tämä tallentuu selkeästi havaittavaksi virtuaalisella oppimisalustalla.

Opettajat määrittelivät oppimistilaansa osaltaan myös mentorin kautta: ”Mentorilta sai kyllä aina palautetta ja tukea, jos sitä tarvitsi.” (o4). Enemmän kuin mentorin roolia, usea opettaja korosti kuitenkin parityöskentelyä arvioinnissa oppimista edistävänä tekijänä. Projekti muodosti ”erittäin toimivan (oppimistilan), koska päädyin parityöhön toisen arvioijan kanssa. Saimme oppia yhteisöllisessä ja toisiamme tukevassa vuorovaikutuksessa.” (o7). Oppimistila syntyi tavallisesti vertaisten kesken.

Yksin ja pareittain työskentelyn yleisyyden vuoksi on syytä pohtia tilannetta. Ongelmat synnyttivät parhaimmillaan yhteisen, hyvän kasvualustan. Tasavertaisena lähtökohtana yhteisessä oppimisprosessissa pidettiin sitä, että verkko-opetus oli kaikille edelleen uutta ja monelta osin epäselvää. Esteitä muilta oppimiseen ja yhteisen oppimistilan syntymiseen muodostivat arviointiryhmän toimimattomuus ja heterogeenisuus ja ajankäytön ongelmat. Opettajat määrittelivätkin yksilöllisen ja yhteisöllisen oppimistilan kokemustaan sitoutumisen kautta. Sitoutuminen loi oppimistilaa, kun taas sitoutumattomuus vaikutti muihinkin estäen yhteisöllisen oppimistilan muodostumisen. Vuorovaikutus oli keskeistä: ”...vuorovaikutteisia menetelmiä käytössä hyvin ja ryhmä oli varsin sitoutunut” (o11). (vrt. Lock 2006, 674.) Jos vuorovaikutusta ei saavutettu, koettiin, että "oppimistila jäi hyvin henkilökohtaiseksi (o4)" tai "hieman monologiseksi" (o19). Oppimistilaan katsottiin keskeisesti kuuluneen mielipiteiden vaihdon ja kokemusten jakamisen, jotta oppimistila olisi jaettu. 
Asenteet verkko-opetusta kohtaan muuttuivat positiivisemmiksi, tapahtui voimaantumista ja ylitettiin esteitä: "Motivaatio omaa työtä kohtaan lisääntyi monta pykälää!” (07). ”Kurssien suunnittelu ja toteutus ei ole niin hankalaa kuin kuvittelin. Voisin itsekin kehitellä kursseja...” (o21). Projektissa opittiin asettumaan opiskelijan asemaan ja oivallettiin verkko-opetuksen toteutuksen erityishaasteita verrattuna lähiopetukseen: "Suunnittelen nettiin opetusta vuorovaikutteisemmin ja annan monipuolisia oppimistehtäviä.” (o14). Opettajat tunnistivat osaamisensa kehittämishaasteita: "Opettelen lisää verkko-opetuksen ohjausta ja opiskelijoiden motivointia.” (o21). Projektin koettiin tarjonneen innostavan ja oivaltavan oppimistilan: "Projekti synnytti minussa innostuksen ja ahaa-elämyksiä verkko-opetuksen käyttämiseksi omassa työssäni. Sain uusia ideoita ja paljon pohdittavaa toisilta arvioijilta - aivan eri aloilta.” (o18). Oppimistila koettiin näin myös voimaannuttavana ja moniammatillisena. Gentry ja kumppanit (2008) totesivat verkossa tapahtuvan mentoroinnin olevan tyypillisesti asenteita muuttava ja ensisijaisesti positiivinen ja innostava kokemus.

Arviointiryhmissä oli havaittavissa jännitteitä toimintavapauden ja yksityiskohtaisten, selkeiden työskentelyohjeiden tarpeen välillä. Mentorit kohdistivat projektin koordinaattoreihin ja opettajat mentoreihin odotuksia selkeästä prosessin ohjeistuksesta. Toisaalta mahdollisuus luoda oma toimintatapa ryhmässä koettiin motivoivana ja mielekkäänä. Oppimistilaa jäsennettiin näin ollen tavoitteellisuuden sekä selkeän työjärjestyksen ja toisaalta luovan keskustelun jännitteellä. Tavoitteellista virtuaalista toimintaa edistivät valmiit esityslistat, aikataulut, selkeät välitehtävät ja säännöllisyys. Toisaalta hedelmällisenä koettiin, että puheenjohtaja salli keskusteluvapauden.

Projektin kommunikointifoorumeita verkossa kuvattiin monin käsittein: fyysisenä oppimistilana, virtuaalisena oppimistilana. Eräs opettaja kuvaa kokemustaan: "Psyykkinen ja sosiaalinen oppimistila kameroineen ja mikrofoneineen oli myös uutta ...häiriötön virtuaalinen oppimistila konkreettisesti oli tärkeää ja siihen panostaminen tuli projektin kuluessa yhä tärkeämmäksi.” (o19). Toisaalta virtuaalinen oppimistila saatettiin kokea hyvin muodollisena ja etäisenä, mihin vaikutti virtuaalisen työskentelyn poikkeavuus perinteisestä vuorovaikutuksesta ja kommunikointivälineiden outous (vrt. Bishop, Giles \& Bryant 2005). Oppimistilaan kuuluvat opettajien vastausten mukaan toimintaan ohjatut ulkoiset resurssit: ”Koska projekti oli kunnolla resursoitu, siihen oli oikeasti mahdollista myös osallistua ja sen myötä oppia” (o14).

Projektin tarjoama oppimistila määriteltiin edelleen uuden tiedon saamisena ja verkkopedagogisen osaamisen päivittämisenä. Opettajat kokivat tarpeelliseksi välittää oppimaansa eteenpäin työpaikoillaan. Oppimistilaan liittyivät myös kehittämisprojektiin osallistuvien opettajien työyhteisöt, kun opettajat jakoivat tietoa kehittämishankkeesta kolleegoille ja opiskelijoille sekä muodollisissa että informaaleissa tilanteissa: ’Esittely lisäsi kiinnostusta toimintaan ja samalla mietimme kuinka voisimme kehittää opetusta omassa koulussamme.” (o19). Oppimistilaa kuvattiin vielä keskeneräisenä prosessina. Heränneisiin kysymyksiin toivotaan löydettävän vastauksia.

\section{Verkkopedagogista ajattelua ja laadunarvioinnin käytänteitä}

Projektin tavoite aktivoida osallistujia reflektoimaan verkko-opetuksen ja pedagogisen laadunarvioinnin käytäntöjä ja haasteita uusimman verkkopedagogisen tiedon näkökulmasta toteutui useimpien osallistuneiden opettajien mukaan hyvin, vaikka ryhmien toiveet ja kokemukset vaihtelivatkin. Opettajat kokivat oppineensa ja saaneensa opetukseensa suoraan hyödynnettävissä olevia käytännön taitoja ja välineitä (arviointikriteeristö, yhteiset havainnot).

Projektin avulla virtuaalityöskentely saattoi tulla osaksi opettajien oman opetuksen arkea: ”Opin toimimaan luontevasti verkon välityksellä, uutuudenviehätys vaihtui normaalitoiminnaksi.” (o11). Kokemus innosti opettajia virtuaalitiimityöskentelyyn omassa opetustyössään ja työyhteisöjä ottamaan opetus- ja palaverikäyttöön projektin työkaluja. Näin hankittiin myös globaalin työn ja koulutuksen edellyttämiä taitoja.

Leskelän (2007) mukaan mentoroitavan yksittäiset tiedot ja taidot lisääntyvät ja hän saa hyödyllistä tietoa ja informaatiota. Tutkimuksemme antaa viitteitä siitä, että osassa ryhmistä oppimisprosessissa oli päästy informaation jakamista pidemmälle yhteisen tiedon rakentamisen suuntaan. Opettajat kokivat verkkopedagogisen osaamisensa lisääntyneen ja he kasvoivat ammatillisesti: ”Virtuaalikurssi ja sen arviointi on elävää elämää työssäni ja kiinnostus luoviin ratkaisuihin on olemassa.” (o23).

Leskelän (2007) sekä Klasenin ja Clutterbuckin 
(2004) mukaan toimijoiden verkostot laajenevat mentorointiprojektissa: ”Itse koen sen, että kuinka valtavan hyvä verkostointimahdollisuus tämä on, alkaa olla jokaisesta ammattikorkeakoulusta tuttuja” (mentori). Syntynyttä kollegaverkostoa aiottiin hyödyntää jatkossakin ja saatettiin sopia jatkotoimista.

Opettajat oppivat käyttämään uusia digitaalisia työvälineitä ja saivat kokemuksia virtuaalisesta vuorovaikutuksesta ja tiimityöstä. Virtuaalipalaverit, äänen ja kuvan käyttö kirjoittamismahdollisuuksien lisäksi koettiin mielenkiintoisena. ”Tällainen nettipalaverien pitäminen on ollut minulle paljon mahdollistava ja verkko-opetusta laajentava, se lisää kanssakäymistä ja yhteisöllisyyttä” (nauhoitus). Keskitetty tekninen tuki koettiin tärkeäksi opeteltaessa käyttämään ohjelmistoja, mutta lisäksi tarvittiin teknistä tukea omalta työpaikalta, koska kaikki ongelmat eivät ratkenneet etäneuvonnan kautta. Tämäkin projekti osoitti, että tekniikkaa on aina hyvä testata ennen virtuaalipalaverien alkua.

\section{Rohkaisevaa asiantuntijuutta, vertais- oppimista ja kehittämishaasteita}

Leskelän $(2007,172)$ mukaan mentori tarjoaa keskustelukumppanuutta, kokemusta, asiantuntijuutta ja sopivaa täsmäohjausta. Tässä projektissa mentorin tuli ohjata ryhmäänsä verkossa sekä yksilötasolla että yhteisöllisesti. Mentorointi oli monelle opettajista vierasta ja he kohdistivat mentorointiin suuria odotuksia. Etukäteen mentori miellettiin keskustelukumppaniksi, oppimisen kumppaniksi, sparraajaksi, innostajaksi ja rohkaisijaksi. Loppukyselyn perusteella mentorointi vastasi melko hyvin opettajien odotuksia. Asteikolla 4-1 arvioituna, 30,4 prosenttia opettajista antoi mentoroinnille parhaan pistemäärän (4) ja 47,8 prosenttia toiseksi parhaan pistemäärän (3). Vastanneista 82,6 prosenttia katsoi mentoroinnin tarjonneen tukea arviointiprosessiin.

Loppukyselyyn vastanneista opettajista $2 / 3$ koki saaneensa mentorilta henkilökohtaista ohjausta riittävästi tarvitessaan. Opettajat kokivat, että mentoroinnin hyödyntäminen riippui heistä itsestään. Koska asiantuntijamentorointia ei kaikissa ryhmissä hyödynnetty kovin aktiivisesti ja vertainen työpari oli keskeisin oppimisen tuki, voidaan pohtia, kuuluuko opettajien työskentelykulttuuriin pyrkimys työskennellä mahdollisimman itsenäisesti ja pärjätä ilman tarjolla olevaa keskustelu- tukea. Opettajat sitoutuivat vuorovaikutussuhteeseen verkkomentoroinnissa ensisijaisesti teeman ja ryhmän yhteisen tehtävän, ei henkilösuhteen kautta (vrt. Leskelä 2007, 181).

Toimiessaan arvioinnin tukena mentori aktivoi dialogia, tuki ryhmää yhdessä pohtimaan ja oivaltamaan, mutta myös johti ja aikataulutti yhteistä prosessia. Mentorin tavoitteellinen, sisällöllinen ja työskentelyä organisoiva ohjaus edistivät ryhmän toimintaa. Mentori vei prosessia eteenpäin reflektiota tukevilla kysymyksillä: ”...(mentori) aktivoi meitä keskustelemaan keskenämme esittämällä kysymyksiä ja ottamalla itsekin osaa keskusteluun” (a15). Mentori toimi myös roolimallina (Klasen \& Clutterbuck 2004), sillä hänen työskentelystään opettajat saivat vinkkejä omaan työhönsä.

Useimmissa tapauksissa aineistojen arviointi ei ollut vain tehtävän suorittamista, vaan mentoroinnin ja kollegakeskustelun avulla arvioiminen liitettiin laajempaan yhteyteen, verkkopedagogiseen ajatteluun ja reflektioon: ”Se oli hyvänä puolena, kun joutui panostamaan tällaiseen toisenlaiseen ajatteluun. Ei joutunut ainoastaan sisältöjä tässä tuijottamaan” (nauhoitus). Opettajien oppiminen vastasi tunnistettuun osaamisen kehittämisen tarpeeseen (just-in-time-learning) ja oli aitojen työelämän ongelmien ratkomista ja tavoitteellista omaan työhön liittyvän toiminnan kehittämistä (real-time learning) (vrt. Hawkins \& Smith 2006, 122; Parviainen 2006, 165).

Monet aiemmat tutkimukset osoittavat, että mentorella on usein taipumus reflektiota tukevien kysymysten tekemisen sijasta antaa itse faktapohjaisia vastauksia, jolloin he eivät tue osallistujien omia ongelmanratkaisutaitojen ja reflektion kehittymistä (Gentry ym. 2008, 367). Osallistujat kokivat toisilta oppimisen antoisimmillaan yhteisöllisenä prosessina, mutta myös tiedon ja käytäntöjen jakamisena: "Kokemusten ja näkemysten jakaminen ryhmässä sekä ryhmäläisten että mentorin kanssa oli mielekästä ja toi myös osaltaan uusia näkökulmia asioihin.” (a15). ”Kollegat olivat kokeneita opettajina, mutta osa myös verkkotyöskentelijöinä. Heistä oli valtava tuki omalle ajattelulle ja ajattelun jäsentämiselle.” (o19)

Yhteisöllisyys ryhmissä onnistui palautteen mukaan vaihdellen. Eräs opettaja nosti esille ryhmän jäsenen tai mentorin sitoutumisen vaikutuksen oppimismahdollisuuksiin: "Haavoittuvat ryhmät pitäisi jotenkin paikata, jotta henkilöt, joita asia kiinnostaa pääsevät jakamaan ja saamaan koke- 
muksia ja palautetta”. Vuorovaikutusta estäneitä tekijöitä tunnistettiin sekä mentorin ohjauksessa että ryhmän jäsenten toiminnassa: "Ryhmän vetäjällä (mentorilla) on todella suuri vastuu motivoida ja sitouttaa ryhmän jäsenet työskentelemään... Meidän ryhmän jäsenillä oli liian monella täynnä olevat kalenterit ryhmän toimintaa varten... Verkossa toteutettavien opintojen ohjaus on todella haasteellista. Siinä tarvitaan hieman erilaisia taitoja kuin normaalissa vuorovaikutteisessa opetuksessa” (o21). Mentoreiden istunnossa pohdittiin erityisesti, millaisia dialogitaitoja virtuaalisessa ympäristössä tarvitaan. Tämän tutkimuksen puitteissa ei päästy vielä syvällisesti pohtimaan, mitä nuo erityistaidot olisivat. Projektiin valitut työkalut mahdollistivat dialogin, mutta keskustelu saattoi jäädä pinnalliseksi: ”Enemmän pitäisi satsata henkilökohtaiseen dialogiin eikä ns. varovaiseen korkeaan faktapohjaiseen keskusteluun, mikä osaltaan aika ajoittain kiusasi verkkotyöskentelyssä.” (o18). Dialogin syntymisen esteiksi tunnistettiin palautekyselyssä myös projektin lyhytkestoisuus ja prosessin katkaissut kesäkausi. Dialogia edistäviä konkreettisia työtapoja verkossa keskustelussa tulee pyrkiä jatkossa kehittämään mentorien orientaatiokoulutuksessa.

Mentorointi- ja vertaismentorointisuhteen tunnusomainen piirre on keskinäinen tuki ja oppiminen (Bierema \& Hill 2005). Projektissa 2/3 opettajista piti vertaisoppimisen mahdollisuuksia hyvinä ja koki oppineensa muilta. Tällöin oppiminen yleisesti kontekstoitiin nimenomaan omalta arviointiryhmältä oppimiseen. Kollegoilta opittiin projektissa sisällöllisiä asioita, kuten ”arviointikriteerien merkityksiä ja erilaisia tulkintoja niistä” (o2). Kollegojen kanssa keskustellessaan opettaja oppi katselemaan opintojaksoja erilaisista näkökulmista ja hyödyntämään niitä paremmin.

Mitkä toimintatavat ja menetelmät olivat opettajien mielestä toimivia ja sovellettavissa vastaaviin projekteihin? Entä miten opettajat kehittäisivät projektia? Suurin osa opettajista piti kehitettyä mallia toimivana. Projektin toimintatapojen koettiin olevan sovellettavissa muihin projekteihin. Kehittämiskohteena jatkossa nähtiin osallistujien sitoutuneisuuden sekä ajan ja resurssien varmistaminen. Digitaalisten työkalujen tekniset ongelmat vaativat korjausta. Projektin alussa tulee korostaa enemmän yhteisen kehittämiskohteen ja jaettujen työkalujen läpikäymistä ja yhteistä opettelua ryhmissä. Paikallinen tekninen tuki tulee varmistaa. Toiveet ryhmien muodostamisen tavoista vaihtelivat (koulutusalakohtainen vs. monialainen). Ryhmien välistä vuorovaikutusta voitaisiin vahvistaa (vrt. inter-team mentoring, ks. Klasen \& Clutterbuck 2004). Samoin vertaisten keskustelua edistävää parimentorointia toivottiin toimintamallissa lisättävän ryhmissä.

Projektissa toimittiin täysin virtuaalisesti lukuun ottamatta yhden arviointiryhmän alkutapaamista. Virtuaalista työskentelyä pidettiin mielenkiintoisena, odotukset ylittävänä ja palkitsevana kokemuksena. Kuitenkin kehittämisehdotuksissa nousi esille toive ryhmän lähitapaamisista. Jatkuva vuorovaikutussuhteen ylläpitäminen on virtuaalisen kehittämisprojektin ydin. Ryhmien muodostamiseen ja vuorovaikutukseen sitouttamiseen on syytä kiinnittää huomiota.

Virtuaalista ryhmämentorointia pidettiin periaatteessa hyvänä, muualle sovellettavissa olevana käytänteenä (vrt. Gentry ym. 2008). Työskentelyprosessissa tarvitaan asiantuntijaohjaaja. Yhteydenpito mentoriin verkossa voi toimia hyvin ja osassa ryhmiä mentorin vetämiä verkkokeskusteluja pidettiin toimivina. Hyviä käytänteitä virtuaalisessa työskentelyssä olivat myös aineistojen etukäteistoimittaminen yhteiseen työtilaan ennen virtuaalipalaveria sekä palaverien nauhoitus jatkokäyttöön. Projektissa yhdistyi mielekkäällä tavalla sisällöllinen ja menetelmällinen näkökulma: samalla kun opittiin pedagogista laadunarviointia, opittiin uusien työvälineiden käyttöä.

\section{Pohdintaa}

Toimintatutkimuksen tuloksia on arvioitava suhteessa sen osallistujiin, toteutukseen, lähtökohtaan ja prosessiin. Mallin kehittämiseen osallistuneet henkilöt olivat lähtökohtaisesti virtuaaliopetuksesta ja verkko-opetusaineiston tuottamisesta ja kehittämisestä kiinnostuneita opettajia, joiden toiveet, odotukset ja mahdollisuudet oppia projektissa vaihtelivat. Tässä tutkimuksessa kiinnostus kohdistuu toimintamallin piirteiden arviointiin ja kehittämiseen tämän erityisen osallistujajoukon tarpeiden pohjalta, ei niinkään mallin vaikuttavuuden yksinkertaistavaan arviointiin tai sen siirtämiseen mille tahansa opettajaryhmälle.

Projektin tulosten osoittaminen on selkeintä ensimmäisen ja toisen tavoitteen osalta. Virtuaaliammattikorkeakoulun tuotantorenkaissa tuotettujen opintojaksojen pedagoginen laatu arvioitiin tavoitteiden mukaisesti ja aineistoja tehtiin tunnetuiksi. Opintojaksojen arviointikriteerit selkiintyi- 
vät yhteisen kehittelyn tuloksena ja laatutyön tuloksena arvioituja aineistoja ja niiden käytettävyyttä on voitu edelleen kehittää.

Kolmannen tavoitteen mukaisesti luotiin uudenlainen virtuaaliseen ryhmämentorointiin perustuva opettajan osaamisen kehittämisen malli, jossa osallistujien henkilökohtaiset osaamistavoitteet ja oppimistulokset vaihtelivat. Projekti tutustutti opettajia pedagogiseen laadunarviointiin, sen työkaluihin ja menetelmiin kuten virtuaaliseen ryhmätyöhön. Sen avulla kehitettiin verkkopedagogista näkemystä sekä opittiin vuorovaikutuksesta virtuaalisissa ympäristöissä.

Projektia pidettiin tässä opettajaryhmässä kiinnostavana, hyödyllisenä ja antoisana uutta oppimista edistävänä yhteisenä oppimiskokemuksena. Projektiin osallistuminen motivoi opettajaa omassa työssään ja aktivoi verkko-opetuksen kansalliseen kehittämiseen. Uusia kasvun silmuja syntyi sekä yksilöllisen että yhteisöllisen oppimistilan muodostumisen kautta.

Tutkimuksellisesti kriittisenä näkökulmana on, että monimuotoinen, autenttinen kehittämisprojekti ei edes pyri tarjoamaan tasalaatuista oppimiskokemusta toimijoilleen. Millaisia oppimistilasta ja sen tuloksista muodostuu, riippuu esimerkiksi ryhmän tarpeista ja sitoutumisesta, asiantuntijamentorin taidoista sekä virtuaalisten työvälineiden toimivuudesta. Siksi ryhmällä voisi olla valittavanaan myös useampia asiantuntijamentoreita eri asiantuntijuusalueilta (vrt. Welsh 2004), jolloin he voisivat mallintaa toiminnallaan myös jaettua asiantuntijuuutta. Sisällölliset ja toimintatapaan liittyvät ongelmat edistivät parhaimmillaan yhteisöllistä keskustelua ja yhteisen ymmärryksen etsimistä. Oppimisyhteisön jaetut kohteet loivat oppimistilaa, jossa oli mahdollista käsitellä vaikeitakin ammatillisia asioita kollegojen kesken. Asiantuntijuuden syvällisempi kehittyminen yhteisen kohteen kanssa työskentelynä olisi joissakin ryhmissä edellyttänyt pitemmän ajanjakson (vrt. Hakkarainen \& Paavola 2006, 241). Mentorointi vastasi näissäkin tapauksissa opettajan työtehtäviin liittyviä lyhyen aikavälin osaamistavoitteita työsuorituksen parantuessa (vrt. Leskelä 2007, 184).

Virtuaalinen ryhmämentorointi on toimintapa, jolla on annettavaa ja jota voidaan soveltaa etsittäessä opettajien täydennyskoulutukseen uudenlaisia joustavia malleja. Opettajien oppiminen ja osaamisen kehittäminen projektissa perustui itsenäiseen arviointityöskentelyyn, asiantuntijoiden ja vertaisten kollegojen väliseen vuorovaikutuk- seen, yhdessä ongelmien ratkaisemiseen ja toisten ajatuksiin peilaamiseen arviointiryhmissä sekä opitun jakamiseen omissa työyhteisöissä. Jatkossa toimintamallin kehittämishaasteena yhteisöllisemmän oppimistilan synnyttämiseksi nähdään vertaismentoroinnin vahvistaminen.

\section{Lähteet}

Bierema, L. L. \& Hill, J. R. (2005). Virtual mentoring and HRD. Advances in Developing $\mathrm{Hu}$ man Resources 7 (4), 556-568.

Bishop, D. C., Giles, S. M., \& Bryant, K. S. (2005). Teacher receptiveness toward webbased training and support. Teacher and Teacher Education. Vol. 21, 3-14.

Boud, D. (2006). Creating a space for reflection. In Boud, D., Cressey, P. \& Docherty, P. (Eds.) Productive reflection at work. London and New York: Routledge, 158-169.

Cohen, L., Manion, L. \& Morrison, K. (2005). Research methods in education. 5th Edition. London and New York: RoutledgeFalmer.

Colky, D. L. \& Young, W. H. (2006). Mentoring in the virtual organization: keys to build successful schools and businesses. Mentoring \& Tutoring. Vol. 14 (4), 433-447.

Collin, K. (2007). Työssä oppiminen. Teoksessa Collin, K. \& Paloniemi, S. (toim.) Aikuiskasvatus tieteenä ja toimintakenttänä. Jyväskylä: PS-kustannus, 123-154.

Docherty, P., Boud, D. \& Cressey, P. (2006). Lessons and issues for practice and development. Teoksessa Boud, D., Cressey, P. \& Docherty, P. (toim.) Productive reflection at work. London and New York: Routledge, 193206.

Gentry, L. B., Denton, C. A. \& Kurz, T. (2008). Technologically-based mentoring provided to teachers: A synthesis of the literature. Journal of Technology and Teacher Education. Vol. 16 (3), 339-373.

Hakkarainen. K. \& Paavola, S. (2006). Kollektiivisen asiantuntijuuden mahdollisuuksia ja rajoituksia - Kognitiotieteellinen näkökulma. Teoksessa Parviainen, J. (toim.) Kollektiivinen asiantuntijuus. Tampere: Tampereen Yliopistopaino, 214-271.

Hakkarainen, K., Palonen, T., Paavola, S. \& Leh- 
tinen, E. (2004). Communities of networked expertise. Professional and educational perspectives. Earli. Oxford: Elsevier.

Hawkins, P. \& Smith, N. (2006). Coaching, Mentoring and organizational consultancy. Open University Press. Berkshire: McGrawHill Education.

Hezlett, S. A. \& Gibson, S. (2005). Mentoring and human resource development: Where we are and where we need to go. Advances in Developing Human Resources. Vol. 7 (4), 446-469.

Hytönen, T. (2007). Henkilöstön kehittäminen aikuiskasvatuksen työkenttänä. Teoksessa Collin, K. \& Paloniemi, S. (toim.) Aikuiskasvatus tieteenä ja toimintakenttänä. Jyväskylä: PSkustannus, 189-220.

Klasen, N. \& Clutterbuck, D. (2004). Implementing mentoring schemes. Oxford: Elsevier.

Lawless, K. A. \& Pellegrino, J. W. (2007). Professional development in integrating technology into teaching and learning: knows, unknows, and ways to pursue better questions and answers. Review of Educational Re-search. Vol. 77 (4), 575-614.

Le Cornu, R. (2005). Peer mentoring: engaging pre-service teachers in mentoring one another. Mentoring and Tutoring. Vol. 13 (3), 355-366.

Leppisaari, I., Vainio, L., Kleimola, R., HartnellYoung, E. \& Makino, Y. (2006). Comparing online mentoring cases in educational context in Finland, Australia and Japan. In Proceedings of EMCC, November 1-3, 2006, Cologne, Germany.

Leskelä, J. (2007). Mentorointi ammatillisen kasvun edistäjänä. Teoksessa Collin, K. \& Paloniemi, S. (toim.) Aikuiskasvatus tieteenä ja toimintakenttänä. Jyväskylä: PS-kustannus, 155-187.

Lewis, D. \& Allan, B. (2005). Virtual learning communities. Berkshire: Open University Press.

Lock, J. V. (2006). A New Image: Online communities to facilitate teacher professional development. Journal of Technology and Teacher Education. Vol. 14 (4), 663-678.

McDougall, M. \& Beattie, R. S. (1997). Peer mentoring at work: The nature and outcomes of non-hierarchical developmental. Management Learning. Vol. 28 (4), 423-437.

McNiff, J., Lomax, P. \& Whitehead, J. (2005). You and your action research project. 2nd Edition. London and New York: RoutledgeFalmer.

Parviainen, J. (2006). Kollektiivinen tiedonrakentaminen asiantuntijatyössä. Teoksessa Parviainen, J. (toim.) Kollektiivien asiantuntijuus. Tampere: Tampereen Yliopistopaino, 155-187.

Reeves, T, C., Herrington, J. \& Oliver, R. (2004). A Development research agenda for online collaborative learning. ETR\&D. Vol. 52 (4), 53-66.

Suojanen, U. (1992). Toimintatutkimus koulutuksen ja ammatillisen kehittymisen välineenä. Helsinki: Finn Lectura.

Tuomi-Gröhn, T., Engeström, Y. \& Young, M. (2003). From transfer to boundary-crossing between school and work as a tool for developing vocational education: An introduction. In Tuomi-Gröhn, T. \& Engeström, Y. (Eds.) Between school and work: New perspectives on transfer and boundary-crossing. Amsterdam: Pergamon, 1-15.

Welsh, S. C. (2004). Mentoring the future. Cochrane: Momentum Learning Inc.

Viitala, R. (2006). Johda osaamista. Osaamisen johtaminen teoriasta käytäntöön. 2. painos. Helsinki: Infor.

Artikkeli saapui toimitukseen 4.1.2008.

Se hyväksyttiin julkaistavaksi 22.9.2008. 